\title{
Considerations on the use of antihypertensive blockers of the renin-angiotensin system in adults and children in the face of the COVID-19 pandemic
}

\author{
Edmundo Vázquez-Cornejo* \\ Unidad de Apoyo al Predictamen, Hospital Infantil de México Federico Gómez, Mexico City, Mexico
}

\begin{abstract}
As severe acute respiratory syndrome coronavirus 2 (SARS-CoV-2)-infected patients with hypertension and other cardiovascular comorbidities develop more severe coronavirus disease (COVID)-19 and are at high risk of death, a controversy arose about the use of antihypertensives as angiotensin-converting enzyme inhibitors (ACEis) and angiotensin II receptor blockers (ARBs). Such drugs might increase the expression of the fundamental receptor of this new infectious agent: the angiotensin-converting enzyme 2 (ACE2). Preclinical observations indicate that the increase of ACE2 expression or the activity by ACEis and ARBs leads to a greater transformation of angiotensin (Ang)-ll to Ang-(1-7), which is associated with positive effects on cardiovascular and pulmonary pathophysiology. This association has been demonstrated in observational studies in patients with cardiovascular pathology and pneumonia. It has not been possible to confirm whether users of ACEis or ARBs are more infected by the new coronavirus, due to methodological issues in studies with patients infected with SARSCoV-2. However, the use of such antihypertensive treatments in both children and adults might reduce the virulence of infection. Therefore, changes in the antihypertensive therapy of patients at risk of contracting COVID-19 are not recommended.
\end{abstract}

Key words: Coronavirus disease-19. Antihypertensive agents. Angiotensin-converting enzyme 2 enzyme. Ang I (1-7). Severe acute respiratory syndrome coronavirus 2. Pediatrics.

\section{Consideraciones sobre el uso de antihipertensivos bloqueadores del sistema renina-angiotensina en adultos y niños ante la pandemia de COVID-19}

\section{Resumen}

Los pacientes con hipertensión y otra comorbilidad cardiovascular infectados con SARS-CoV-2 desarrollan cuadros más graves de COVID-19 y con mayor frecuencia fallecen. Este hecho ha originado una controversia acerca del uso de antihipertensivos inhibidores de la enzima convertidora de la angiotensina (IECA) y de antagonistas de los receptores de la angiotensina II (ARA-II), pues tales medicamentos pueden incrementar la expresión del receptor funcional de este nuevo agente infeccioso: la enzima convertidora de la angiotensina 2 (ECA2). Las observaciones preclínicas indican que el aumento de la expresión o de la actividad de la ECA2 por uso de IECA o ARA-Il conduce a una mayor transformación 
de angiotensina 2 a a angiotensina 1-7, la cual se asocia con efectos positivos sobre la fisiopatología pulmonar y cardiovascular. En estudios observacionales de pacientes con patología cardiovascular y neumonía se ha confirmado esta asociación. La falta de evidencia contundente debida a aspectos metodológicos en estudios con pacientes infectados con SARS-CoV-2 no permite confirmar si los usuarios de IECA o ARA-Il se contagian más con el nuevo coronavirus. Sin embargo, continuar con tales medicamentos antihipertensivos, tanto en adultos como en niños, podría reducir la virulencia de la infección. Por ello, no se recomienda cambiar la terapia antihipertensiva en los pacientes susceptibles a la COVID-19.

Palabras clave: COVID-19. Antihipertensivos. IECA. Angiotensina. SARS-CoV-2. Pediátricos.

\section{Introduction}

The new coronavirus severe acute respiratory syndrome coronavirus 2 (SARS-CoV-2) has spread worldwide, raising multiple health concerns given the high frequency of cardiovascular comorbidities, particularly hypertension, among patients with severe forms of coronavirus disease (COVID)-19 and those who die'.

The functional receptor that internalizes SARS-CoV-2 in human cells is known to be a transmembrane enzyme, a variant of the angiotensin-converting enzyme (ACE) called ACE2 ${ }^{2-4}$, which is involved in counteracting the effects of ACE on the renin-angiotensin system $\left(\right.$ RAS) ${ }^{5}$. Furthermore, ACE inhibitors (ACEis) and angiotensin II receptor blockers (ARBs) have been shown to dysregulate the ACE/ACE2 balance in preclinical trials ${ }^{6,7}$.

Because both ACEis and ARBs are first-line drugs in the management of high blood pressure, heart failure, and diabetic nephropathy ${ }^{8-10}$, it was hypothesized that these RAS blockers could have negative implications in the pathogenicity or virulence in susceptible patients ${ }^{11-13}$. However, other studies support the cardiac and pulmonary benefits, due to the dysregulation of ACE/ACE2 in patients treated with ACEis and ARBs infected by SARS-CoV-2, equally based on observations in animal models ${ }^{14,15}$, opening a controversy: whether to encourage or discourage the use of ACEis or ARBs in patients susceptible to COVID-19.

Considering that hypertension is a public health problem in Mexico ${ }^{16}$, and recognizing the context of current controversy, several instances have called for caution in the interpretation of preclinical observations and advising against changes in the management of hypertensive patients ${ }^{17-21}$. Therefore, the purpose of this paper was to review the implications of the use of RAS blockers on the pathogenicity or virulence of SARS-CoV-2 and to make recommendations for the management of adults and children with hypertension.

\section{Human SARS-CoV-2 receptor and its associated pathogenicity}

The membrane that surrounds the coronaviruses has glycoproteins embedded in the form of spines called S-proteins. Such structures contain the binding site to the human cell receptor ${ }^{22}$. In the SARS-CoV-2 virus, certain S-binding site amino acids that are important for receptor recognition in human cells have undergone genetic modifications that are energetically favorable to S-protein coupling with $\mathrm{ACE}^{4,23}$, increasing their pathogenicity considerably, compared with other coronaviruses ${ }^{2,24,25}$.

Furthermore, ACE2 is a transmembrane metalloenzyme $^{2,3}$ with carboxypeptidase activity ${ }^{22,26}$, whose expression is abundant in the small intestine, kidney, and cardiac muscle but scarce in the pulmonary alveolar epithelium ${ }^{25,27}$.

The pathogenicity of SARS-CoV-2 is very efficient in cells with low membrane ACE2 expression. Recent observations suggest that more non-described human receptors could contribute to its virulence ${ }^{28}$. In addition, a soluble fraction of ACE2 does not internalize the virus into the cell but may mediate the immune response at the respiratory mucosa ${ }^{29}$.

\section{Effects of COVID-19 on RAS components}

Two angiotensin (Ang) oligopeptides that mediate antagonistic effects in RAS, known as Ang-II and Ang(1-7), are involved in the pathophysiology of hypertension and other cardiovascular conditions, as well as in SARSCoV-2 infection ${ }^{5,7}$. Moreover, ACE transforms Ang-I into Ang-II, whose interaction with the Ang-II type 1 receptor (AT1) produces vasoconstriction, endothelial dysfunction in the vascular walls, as well as inflammation and cell growth ${ }^{5}$. ACE2 transforms Ang-I and II, producing Ang(1-9) and Ang-(1-7), respectively. The latter binds to the Mas receptor, enhancing the vasodilation effects of bradykinins, inhibiting smooth muscle proliferation in arteries, the synthesis of collagen and certain cardiac proteins induced by Ang- $\|^{26,30}$, as well as mediating 


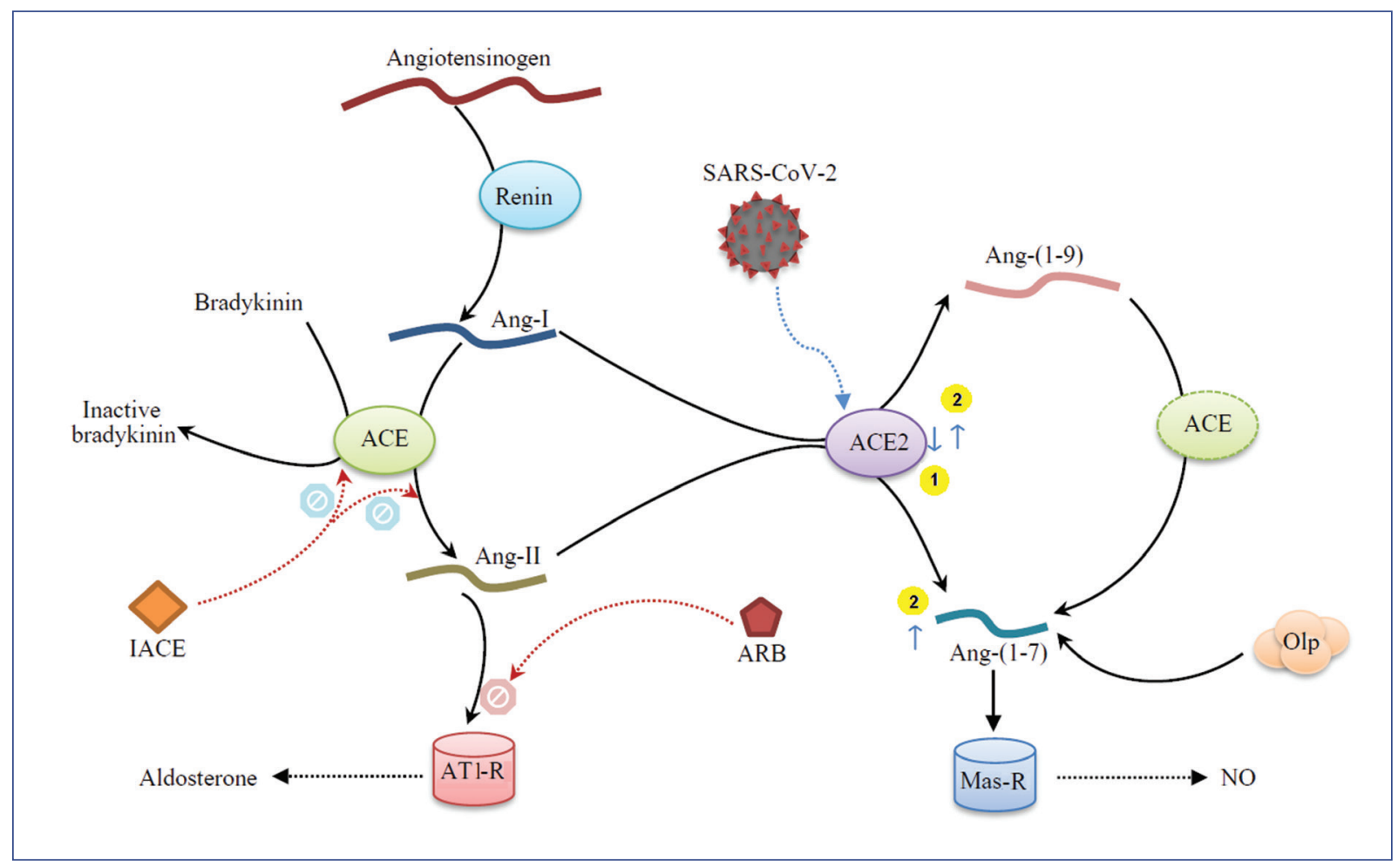

Figure 1. Main interactions between SARS-CoV-2 and the enzymatic and oligopeptide components involved when reninangiotensin system blockers are used. 1. ACE2 reduction during coronavirus infection. 2. Increase of ACE2 and Ang-(1-7) followed by the use of ACEis and ARBs. ACE: angiotensin-converting enzyme; ACE2: angiotensin-converting enzyme 2; ACEis: angiotensin-converting enzyme inhibitors; Ang: angiotensin; ARBs: angiotensin II receptor blockers; AT1R: angiotensin II receptor type 1; MasR: Mas receptor. NO: nitric oxide; Olp: oligopeptidase and neprilysin (in blood circulation).

anti-inflammatory effects and improving the sensitivity of baroreceptors ${ }^{5,31,32}$. ACE is not only enzyme that produces Ang-(1-7) from Ang oligopeptides. Oligopeptidases thimet and prolyligopeptidase also produce Ang (1-7) in the vascular endothelium and smooth muscle; in the kidney, neprilysin produces the largest amount of Ang(1-7) found in the bloodstream (Fig. 1) ${ }^{26}$.

SARS-CoV-2 may decrease tissue expression of ACE2, as observed in mouse lung tissue. The immediate effects of this decrease were increased levels of Ang-II at the lung ${ }^{33}$, increased vascular permeability, neutrophil accumulation, pulmonary edema and injury, and impaired respiratory function $6,31,33,34$. Clinically, this RAS imbalance has been observed in adults with severe COVID-19. These patients developed pneumonia and acute respiratory distress syndrome ${ }^{35}$, accompanied by increased Ang-Il levels in the circulation, which correlates directly with SARS-CoV-2 viral load ${ }^{36}$. More evidence of RAS disorders in the cardiovascular system has been described. The severity of COVID-19 was associated with acute heart damage ${ }^{37}$. Considering that local ACE2 produces most of the Ang-(1-7) in heart tissue (which is a component of cardiovascular regulation ${ }^{26,30,38,39}$ ), the loss of membrane ACE2 will favor the overexpression of pro-inflammatory mechanisms, leading to damage ${ }^{40,41}$.

\section{COVID-19 in hypertensive patients}

A meta-analysis showed that high blood pressure is the most common comorbidity among patients hospitalized for COVID-19, with a frequency of $10.1 \%$ $23.6 \%{ }^{42}$. Furthermore, high blood pressure is associated with an increased disease progression (odds ratio [OR] = 3.0; 95\% confidence interval [Cl] 1.5-5.9), admission to intensive care $(\mathrm{OR}=2.1,95 \% \mathrm{Cl} 1.3-3.3)$, poor outcomes during hospitalization $(\mathrm{OR}=2.2,95 \% \mathrm{Cl} 1.8$ 2.4), and mortality in patients hospitalized for COVID-19 $(\mathrm{OR}=2.11,95 \% \mathrm{Cl} 1.7-2.8)^{43}$. These associations with hypertension also appear to be influenced by gender 
in adults ${ }^{43}$, possibly because men express more ACE2 in lung cells than women ${ }^{44}$.

Interestingly, only $3 \%$ of children with COVID-19 develop a severe or critical illness; however, the characteristic signs and symptoms of the disease differ between children and adults. Furthermore, SARSCoV-2 appears less pathogenic in children than SARS$\mathrm{CoV}^{45,46}$. The overall prevalence of childhood hypertension is low $(4 \%)^{47}$ and is predominantly secondary to other identifiable causes $(57 \%)^{10,48}$. Therefore, the information available regarding RAS in children is scarce.

Consequently, it is important to explore the role of age and aging on the function of RAS components. Although the occurrence of chronic disease is associated with $\mathrm{age}^{49}$, and both with mortality in patients with COVID-1950-52, it is not clear that the enzyme components of RAS are modified only by age in adults ${ }^{53}$, where gender appears to play a differentiating role during aging ${ }^{54,55}$. In contrast, age does exert an important influence on Ang-I and Ang-II concentrations among children and adolescents. Although these enzymes decrease progressively from birth and during childhood, they remain higher than in healthy adults except for Ang-(1-7), of which there are few studies in children and adolescents ${ }^{56}$. Recently, gene expression of ACE2 in nasal epithelial cells has been reported to be positively correlated with age in patients between 4 and 60 years, with and without asthma (being lower at younger ages $)^{57}$, suggesting an explanation for the limited severity of COVID-19 in children.

The absence of differences between the expression of ACE2 and other RAS components by age groups ${ }^{53}$ may be explained by the fact that the accumulated fraction in bronchoalveolar lavage fluid, as well as concentrations in human plasma, is not quantitatively representative of expression at the cell membrane ${ }^{29,58}$, thus being inappropriate indicators of ACE2 activity ${ }^{59}$. Moreover, there are other hypotheses about the lower virulence of SARS-CoV-2 in children, not related to ACE2 but rather to children's mobility, absence of comorbidities, better respiratory tract status, increased innate immune response efficiency, and the supposed benefit attributed to certain vaccines ${ }^{60-62}$.

Despite the above, it is not yet possible to affirm that patients with arterial hypertension are more likely to be infected with COVID-19, since neither the increase in membrane level of ACE2 in hypertensive patients nor the increased SARS-CoV-2 pathogenicity, alone are sufficient factors for this to occur. Studies evaluating comparative cohorts of hypertensive patients using
RAS-blocking drugs that include hypertensive patients not treated by these drugs, and healthy individuals are required to confirm whether the infection rate is different between these groups. Since $81 \%$ of the COVID-19 cases are mild and will not seek medical attention ${ }^{52,63}$, hospital selection bias is relevant in the epidemiological reports available so far. Only in one sufficiently large but not yet published report, history of hypertension was observed in $24 \%$ of individuals with confirmed COVID-19, covering those with outpatient and inpatient care $^{64}$, but there are no cohorts and no distinction between ACEi or ARB users, but rather a large number of cases, so it is not yet possible to draw any conclusions.

\section{ACEis, ARBs, and the modification of RAS components in preclinical models}

The administration of losartan in mice reversed the dysregulation of RAS components produced by SARS$\mathrm{CoV}$ and the severity of lung damage ${ }^{33,34}$. Multiple preclinical trials have shown that the administration of ACEi increases the expression of ACE2 in ranges of $50 \%$ up to 5 times, while ARBs increase it between $30 \%$ and 9 times. These drugs also increase the tissue concentration of Ang-(1-7), ARBs increase it between $10 \%$ and 2 times and ACEis between $20 \%$ and $70 \%$. The extent of the effect may be due to methodological variations, use of different animal species or models, tissues analyzed, multiple compared groups (healthy or sick without treatment), and drugs tested ${ }^{65-74}$.

Of these trials, four evaluated the effects of RAS blockers in healthy animals ${ }^{66,67,71,75}$. In three of these, administration of lisinopril, telmisartan, or losartan did not have consistent results in increasing the expression of messenger RNA (mRNA) of ACE2 in the cardiac muscle $^{66,67}$ or renal arterioles ${ }^{71}$. Nevertheless, the administration of ARBs produced an increase in ACE2 activity $^{66,67,71}$, as well as a tissue increase in Ang-(1-7) and Ang-II substantially reflected in plasma ${ }^{66,67,71,75}$. In addition, one study demonstrated the paradoxical reduction of the expression of the Ang-(1-7) Mas receptor in cardiac muscle ${ }^{67}$; no RAS blocker modified the expression of endothelial neprilysin ${ }^{66,67}$.

In animal models with some cardiovascular pathology, it was observed that the administration of ACEis (lisinopril or enalapril) or ARBs (losartan or olmesartan) produced an increase in ACE2 mRNA, both in renal smooth muscle and cardiac muscle, including the carotid artery ${ }^{65,68-70,73}$; in two studies, increased ACE mRNA expression was also observed ${ }^{69,70}$. Although in 
most trials, increases in ACE2 cell activity in kidney, heart, and plasma were equally seen after ACEis and ARBs treatment ${ }^{68-70,72}$, the expression in cardiac tissue was not always different with and without treatment ${ }^{73,74}$. Finally, models of hypertension showed that ACEis and ARBs effect on the Mas and AT1 receptors expression is tissue dependent, both reduced the AT1 receptor expression in the kidney, in addition to normalizing its expression in the heart; only lisinopril reduced the Mas expression in the kidney ${ }^{69}$.

\section{Clinical use of ACEis or ARB-II and how it is associated with COVID-19 patients}

It has been observed that in users of ACEis, with various cardiovascular conditions, the risk of severe pneumonia is reduced by $45-20 \%$. Furthermore, they present $27 \%$ reduction in mortality; this reduction is not observed among users of ARBs ${ }^{76}$. Similarly, in a prognostic study, it was reported that mortality from sepsis at 90 days was reduced among patients using ACEis or ARBs compared to non-users ${ }^{77}$. Furthermore, the ACE2 soluble fraction could be increased in hypertensive patients treated with ACEis and ARB-II, since in a cohort study, an increase in urinary excretion of this enzyme was observed in users compared to non-us$\mathrm{ers}^{78}$. In such cases, ACEis or ARBs users, who are susceptible to infection with SARS-CoV-2, may have a reduced risk of severe pneumonia and progression to respiratory failure, being complications of severe COVID-1935,50,79; therefore, it is not recommended to discontinue RAS blocking medications.

Among patients with chronic heart failure, treatment with ACEis allows a reduction of Ang II and improves the plasma ratio of Ang-(1-7)/Ang-II, which prevents ventricular remodeling. In contrast, blockade of the AT1 receptor in patients with acute heart failure with decreased ejection fraction may increase mortality and prolong hospitalization ${ }^{80,81}$; in such cases, therapeutic management should avoid the accumulation of Ang-II and reduction of the Ang-(1-7)/Ang-II ratio, preferably with ACEis.

Therefore, the following consideration should be made; Ang-(1-7) levels are associated with the degree of heart failure, when cardiomyopathy or advanced heart failure is present, Ang-II levels are much higher, despite $\mathrm{ACEis}{ }^{80}$. This may indicate that plasma levels of Ang-(1-7) are dependent on neprilysin and other peptidases when the severity of the imbalance between ACE and ACE2 is too pronounced ${ }^{26}$. Recently, in a cohort of 42 patients infected with SARS-CoV-2 with
Grade II and III hypertension, severe cases were observed less frequently among ACEis or ARBs users ( $24 \%$ users vs. $48 \%$ non-users), but without statistical significance due to the small size of the cohorts ${ }^{82}$. There was no difference in viral load between RAS blocker users and non-users ${ }^{82}$, indicating that the mechanisms of protection of RAS blocker antihypertensive drugs against SARS-CoV-2 infection may be much more complex and indirect and that the levels of ACE2 and Ang(1-7) vary by the age and sex of individuals ${ }^{44}$.

In this regard, other hypotheses indicate that patients treated by RAS blockers would benefit by avoiding, to some extent, the cytopenia of CD3+ and CD8+ T cells ${ }^{82,83}$ observed in $64 \%$ of patients hospitalized with COVID-19 $9^{39,79,84}$, and whose magnitude is greater among the deceased compared to survivors ${ }^{50,79}$. Considering the association between inflammation and the worsening of COVID-1925,50,51,79,84, it is desirable to continue treatments with ACEis and ARBs in all susceptible patients.

Two additional aspects should be considered: first, the progression of cardiovascular disease in patients with hypertension may facilitate complications of COVID-19. At the community level, $64 \%$ of antihypertensive drugs prescribed in adults are ACEis and 16\% are ARBs. However, in Mexico City, only 38\% and 27\% of ACEis and ARB users have their hypertension under control, respectively ${ }^{85}$, so the benefits of increased ACE2 may be greater in patients with less advanced chronic conditions ${ }^{80}$. Second, from a pharmacological point of view, ACEis and ARBs differ considerably in their histological distribution: ACEis usually have larger distribution volumes than ARBs, influencing their ability to modify the local intrinsic RAS system ${ }^{8}$, which is responsible for the higher concentration of Ang-II and Ang-(1-7) in tissues ${ }^{5}$. Possibly for that reason, ACEis and ARBs do not regulate mRNA, ACE, and ACE2 expression equally in all tissues ${ }^{73,74}$, and this regulation may be dose dependent ${ }^{32}$.

Particularly in children with essential or renovascular hypertension, no reports are warning of any risk from the use of antihypertensive ACEis or ARBs concerning COVID-19. In these patients, the plasma concentration of Ang-(1-7) is increased by 1.5 times as a compensation for the dysregulation of Ang-I and Ang-II ratio, being especially beneficial the use of ACEis in hypertensive children who are not in a terminal stage ${ }^{86,87}$. It should be noted that the safety and efficacy of adult-related antihypertensive drugs have not been reassessed in pediatric populations ${ }^{10,48}$, and therefore, it is not advisable to change treatment regimens either. It should also 
be noted that, unlike hypertensive adults, not all cases of childhood hypertension require pharmacological treatment ${ }^{10}$.

\section{Other drugs that affect the ACE2 expression}

In preclinical models, statins and ibuprofen have been shown to increase the expression of ACE2, reversing atherosclerosis in rabbits, and cardiac fibrosis in rats ${ }^{88,89}$. Furthermore, cohort studies showed that continuing statin therapy during hospitalization in patients with viral pneumonia is associated with $74 \%$ mortality risk reduction; likewise, continuing treatment with ACEis or ARBs in hospitalized patients is associated with $75 \%$ reduction in mortality. Continuing both treatments are also associated with reduced hospital stay and risk of intubation ${ }^{90,91}$. For hospital management of ACEis and statin users, discontinuation of RAS blockers on admission is associated with an increased risk of mortality $(\mathrm{OR}=3.02, \mathrm{Cl} 1.3-7.0)^{91}$.

Few mild cases of COVID-19 have been reported that worsened after taking ibuprofen ${ }^{92,93}$. Ibuprofen increases both ACE2 and Ang-(1-7) in tissues ${ }^{89}$, this generated a discussion similar to that presented with RAS blockers about whether its use increases the risk of infection or protects against certain pathophysiological processes produced by SARS-CoV-2; the resolution of this conflict is theoretically unsolvable. However, it has been suggested that previous use of nonsteroidal anti-inflammatory analgesics could complicate the hospital course of cases with pneumonia ${ }^{94}$. In such circumstances, replacement with paracetamol does not involve any underlying complications, in contrast with any change in the anti-hypertension therapies, which involve periods of adaptation and medical monitoring for the risk of adverse events.

Preclinical studies are a guide, not always easy to interpret, for translational research in the clinical field, so it is not appropriate to extrapolate their results. The evidence presented here does not allow us to state that patients with hypertension become more ill with COVID19 as a result of receiving treatment with ACEis or ARBs. However, it is possible that the use of ACEis or ARBs in infected patients may confer some protection against the occurrence of respiratory complications, cardiovascular damage, and severe inflammation produced by the new coronavirus virulence mechanisms. In the absence of stronger evidence and the ever-present risk of adverse events, it is desirable and advisable that the administration of RAS blocking drugs be continued during hospitalization and not to modify the antihypertensive therapy of adult or child patients.

\section{Ethical disclosures}

Protection of human and animal subjects. The authors declare that no experiments were performed on humans or animals for this study.

Confidentiality of data. The authors declare that they have followed the protocols of their work center on the publication of patient data.

Right to privacy and informed consent. The authors have obtained the written informed consent of the patients or subjects mentioned in the article. The corresponding author is in possession of this document.

\section{Conflicts of interest}

The authors declare that they have no conflicts of interest.

\section{Funding}

None.

\section{References}

1. Wu Z, McGoogan JM. Characteristics of and important lessons from the coronavirus disease 2019 (COVID-19) outbreak in China summary of a report of 72314 cases from the Chinese center for disease control and prevention. JAMA. 2020;323:1239-42.

2. Yan R, Zhang Y, Li Y, Xia L, Guo Y, Zhou Q. Structural basis for the recognition of SARS-CoV-2 by full-length human ACE2. Science. 2020;367:1444-8.

3. Li W, Moore MJ, Vasilieva N, Sui J, Wong SK, Berne MA, et al. Angiotensin-converting enzyme 2 is a functional receptor for the SARS coronavirus. Nature. 2003;426:450-4

4. Ortega JT, Serrano ML, Pujol FH, Rangel HR. Role of changes in SARSCoV-2 spike protein in the interaction with the human ACE2 receptor: an in silico analysis. EXCLI J. 2020;19:410-7.

5. Te Riet L, van Esch JH, Roks AJ, van den Meiracker AH, Danser AH. Hypertension: renin-angiotensin-aldosterone system alterations. Circ Res. 2015;116:960-75.

6. Danser AH, Epstein M, Batlle D. Renin-angiotensin system blockers and the COVID-19 pandemic: at present there is no evidence to abandon renin-angiotensin system blockers. Hypertension. 2020;75: 1382-5

7. Gheblawi M, Wang K, Viveiros A, Nguyen Q, Zhong JC, Turner AJ, et al. Angiotensin converting enzyme 2: SARS-CoV-2 receptor and regulator of the renin-angiotensin system. Circ Res. 2020;126:1456-74.

8. Hilal-Dandan R. Renina y angiotensina. In: Brunton L, Chabner B, KnoIlman B, editors. Goodman and Gilman Las Bases Farmacológicas de la Terapéutica. Mexico: McGraw-Hill; 2012. p. 721-43.

9. Farooq U, Ray SG. 2014 Guideline for the Management of High Blood Pressure (Eighth Joint National Committee): Take-Home Messages. Med Clin North Am. 2015;99:733-8.

10. Benenson I, Waldron FA, Porter S. Pediatric hypertension: a guideline update. Nurse Pract. 2020;45:16-23.

11. Diaz JH. Hypothesis: angiotensin-converting enzyme inhibitors and angiotensin receptor blockers may increase the risk of severe COVID-19. J Travel Med. 2020;27:1-7.

12. Gurwitz D. Angiotensin receptor blockers as tentative SARS-CoV-2 therapeutics. Drug Dev Res. 2020;2020:1-4.

13. Kuster GM, Pfister $O$, Burkard T, Zhou Q, Twerenbold R, Haaf $P$, et al SARS-CoV2: should inhibitors of the renin-angiotensin system be withdrawn in patients with COVID-19? Eur Heart J. 2020;41:1801-3. 
14. Bavishi C, Maddox TM, Messerli FH. Coronavirus disease 2019 (COVID-19) infection and renin angiotensin system blockers. JAMA Cardiol. 2020;2020:E1-3.

15. Vaduganathan $M$, Vardeny $O$, Michel $T$, McMurray JJV, Pfeffer MA Solomon SD. Renin-angiotensin-aldosterone system inhibitors in patients with covid-19. N Engl J Med. 2020;382:1653-9.

16. Instituto Nacional de Salud Pública. Encuesta Nacional de Salud y Nutrición de Medio Camino. Mexico: Instituto Nacional de Salud Pública; 2016. Available from: https://ensanut.insp.mx/encuestas/ensanut2016/ index.php. [Last accessed on 2020 Apr 16].

17. European Society of Cardiology. Position Statement of the ESC Council on Hypertension on ACE-inhibitors and Angiotensin Receptor Blockers. Sophia Antípolis: European Society of Cardiology; 2020. Available from: https://www.escardio.org/Councils/Council-on-Hypertension-(CHT)/ News/position-statement-of-the-esc-council-on-hypertension-on-ace-inhibitors-and-ang. [Last accessed on 2020 Mar 08].

18. American Heart Association. HFSA/ACC/AHA Statement Addresses Concerns Re: using RAAS Antagonists in COVID-19. Dallas: American Heart Association; 2020. Available from: https://www.acc.org/latest-in-cardiology/articles/2020/03/17/08/59/hfsa-acc-aha-statement-addresses-concerns-re-using-raas-antagonists-in-covid-19. [Last accessed on 2020 Apr 08]

19. Gupta R, Misra A. Contentious issues and evolving concepts in the clinical presentation and management of patients with COVID-19 infection with reference to use of therapeutic and other drugs used in co-morbid diseases (hypertension, diabetes etc). Diabetes Metab Syndr. 2020; 14:251-4.

20. Hanff TC, Harhay MO, Brown TS, Cohen JB, Mohareb AM. Is there an association between COVID-19 mortality and the renin-angiotensin system? A call for epidemiologic investigations. Clin Infect Dis. 2020;71: 870-4.

21. International Society of Hypertension. A Statement from the International Society of Hypertension on COVID-19. Edinburgh: International Society of Hypertension; 2020. Available from: https://ish-world.com/news/a/A-statement-from-the-International-Society-of-Hypertension-on-COVID-19/. [Last accessed on 2020 Apr 07].

22. Kuhn JH, Li W, Choe H, Farzan M. Angiotensin-converting enzyme 2: a functional receptor for SARS coronavirus. Cell Mol Life Sci. 2004:61:2738-43.

23. Li W, Zhang C, Sui J, Kuhn JH, Moore MJ, Luo S, et al. Receptor and viral determinants of SARS-coronavirus adaptation to human ACE2. EMBO J. 2005;24:1634-43.

24. Wan Y, Shang J, Graham R, Baric RS, Li F. Receptor recognition by the novel coronavirus from Wuhan: an analysis based on decade-long structural studies of SARS coronavirus. J Virol. 2020;94:1-9.

25. Chen Y, Guo Y, Pan Y, Zhao ZJ. Structure analysis of the receptor binding of 2019-nCoV. Biochem Biophys Res Commun. 2020:525:135-40.

26. Varagic J, Trask AJ, Jessup JA, Chappell MC, Ferrario CM. New angiotensins. J Mol Med (Berl). 2008;86:663-71.

27. Xu H, Zhong L, Deng J, Peng J, Dan H, Zeng X, et al. High expression of ACE2 receptor of 2019-nCoV on the epithelial cells of oral mucosa. Int J Oral Sci. 2020;12:1-5

28. Wang X, Xu W, Hu G, Xia S, Sun Z, Liu Z, et al. SARS-CoV-2 infects T lymphocytes through its spike protein-mediated membrane fusion. Cell Mol Immunol. 2020;2020:1-3.

29. Jia HP, Look DC, Tan P, Shi L, Hickey M, Gakhar L, et al. Ectodomain shedding of angiotensin converting enzyme 2 in human airway epithelia. Am J Physiol Lung Cell Mol Physiol. 2009;297:L84-96.

30. Crackower MA, Sarao R, Oudit GY, Yagil C, Kozieradzki I, Scanga SE, et al. Angiotensin-converting enzyme 2 is an essential regulator of heart function. Nature, 2002:417:822-8.

31. South AM, Diz D, Chappell MC. COVID-19, ACE2 and the cardiovascular consequences. Am J Physiol Heart Circ Physiol. 2020;318:H1084-90.

32. Keidar S, Kaplan M, Gamliel-Lazarovich A. ACE2 of the heart: from angiotensin I to angiotensin (1-7). Cardiovasc Res. 2007;73:463-9.

33. Kuba K, Imai Y, Rao S, Gao H, Guo F, Guan B, et al. A crucial role of angiotensin converting enzyme 2 (ACE2) in SARS coronavirus-induced lung injury. Nat Med. 2005;11:875-9.

34. Imai Y, Kuba K, Penninger JM. The discovery of angiotensin-converting enzyme 2 and its role in acute lung injury in mice. Exp Physiol. 2008;93:543-8.

35. Wu C, Chen X, Cai Y, Xia J, Zhou X, Xu S, et al. Risk factors associated with acute respiratory distress syndrome and death in patients with coronavirus disease 2019 pneumonia in Wuhan, China. JAMA Intern Med. 2020;58:713-4

36. Liu Y, Yang Y, Zhang C, Huang F, Wang F, Yuan J, et al. Clinical and biochemical indexes from 2019-nCoV infected patients linked to viral loads and lung injury. Sci China Life Sci. 2020;63:364-74.

37. Li JW, Han TW, Woodward M, Anderson CS, Zhou H, Chen YD, et al. The impact of 2019 novel coronavirus on heart injury: a systematic review and meta-analysis. Prog Cardiovasc Dis. 2020;2020:3.

38. Zhou X, Zhang P, Liang T, Chen Y, Liu D, Yu H. Relationship between circulating levels of angiotensin-converting enzyme 2-angiotensin-(1-7)-MAS axis and coronary heart disease. Heart Vessels. 2020; $35: 153-1$
39. Patel SK, Velkoska $E$, Burrell LM. Emerging markers in cardiovascular disease: where does angiotensin-converting enzyme 2 fit in? Clin Exp Pharmacol Physiol. 2013;40:551-9.

40. Haga S, Yamamoto N, Nakai-Murakami C, Osawa $Y$, Tokunaga $K$ Sata T, et al. Modulation of TNF-alpha-converting enzyme by the spike protein of SARS-COV and ACE2 induces TNF-alpha production and facilitates viral entry. Proc Natl Acad Sci U S A. 2008;105:7809-14.

41. Patel VB, Clarke N, Wang Z, Fan D, Parajuli N, Basu R, et al. Angiotensin II induced proteolytic cleavage of myocardial ACE2 is mediated by TACE/ADAM-17: a positive feedback mechanism in the RAS. J Mol Cell Cardiol. 2014:66:167-76.

42. Emami A, Javanmardi F, Pirbonyeh N, Akbari A. Prevalence of underlying diseases in hospitalized patients with COVID-19: a systematic review and meta-analysis. Arch Acad Emerg Med. 2020;8:1-14.

43. Pranata R, Lim MA, Huang I, Raharjo SB, Lukito AA. Hypertension is associated with increased mortality and severity of disease in COVID-19 pneumonia: a systematic review, meta-analysis and meta-regression. $\mathrm{J}$ Renin Angiotensin Aldosterone Syst. 2020;21:1-11.

44. Li Y, Zhou W, Yang L, You R. Physiological and pathological regulation of ACE2, the SARS-CoV-2 receptor. Pharmacol Res. 2020;157:1-7.

45. de Souza TH, Nadal JA, Nogueira RJ, Pereira RM, Brandão MB Clinical manifestations of children with COVID-19: a systematic review. Pediatr Pulmonol. 2020;55:1892-9.

46. Chang TH, Wu JL, Chang LY. Clinical characteristics and diagnostic challenges of pediatric COVID-19: a systematic review and meta-analysis. J Formos Med Assoc. 2020;119:982-9.

47. Song $P$, Zhang Y, Yu J, Zha M, Zhu Y, Rahimi Z, et al. Global prevalence of hypertension in children: a systematic review and meta-analysis. JMA Pediatr. 2019:173:1-10.

48. Rao G. Diagnosis, epidemiology, and management of hypertension in children. Pediatrics. 2016;138:1-13.

49. Buford TW. Hypertension and aging. Ageing Res Rev. 2016;26:96-111.

50. Zhou F, Yu T, Du R, Fan G, Liu Y, Liu Z, et al. Clinical course and risk factors for mortality of adult in patients with COVID-19 in Wuhan, China: a retrospective cohort study. Lancet. 2020;395:1054-62.

51. Grasselli G, Zangrillo A, Zanella A, Antonelli M, Cabrini L, Castelli A, et al. Baseline characteristics and outcomes of 1591 patients infected with SARS-CoV-2 admitted to ICUs of the Lombardy region, Italy. JAMA. 2020;323:1574-81.

52. China CDC Weekly. Vital Surveillances: The Epidemiological Characteristics of An Outbreak of 2019 Novel Coronavirus Diseases (COVID-19)-China. Beijing: China CDC Weekly; 2020. Available from: http:// weekly.chinacdc.cn/en/article/id/e53946e2-c6c4-41e9-9a9b-fea8db1a8f51. [Last accessed on 2020 Apr 24].

53. Schouten LR, van Kaam AH, Kohse F, Veltkamp F, Bos LD, de Beer FM, et al. Age-dependent differences in pulmonary host responses in ARDS: a prospective observational cohort study. Ann Intensive Care. 2019;9:1-9.

54. Fernández-Atucha A, Izagirre A, Fraile-Bermúdez AB, Kortajarena M, Larrinaga GL, Martinez-Lage $P$, et al. Sex differences in the aging pattern of renin-angiotensin system serum peptidases. Biol Sex Differ. 2017;8:1-8.

55. Swärd P, Edsfeldt A, Reepalu A, Jehpsson L, Rosengren BE, Karlsson MK. Age and sex differences in soluble ACE2 may give insights for COVID-19. Crit Care. 2020;24:1-3.

56. Sueccenbach FK, Burckhardt BB. Levels of angiotensin peptides in healthy and cardiovascular/renal-diseased paediatric population-an investigative review. Heart Fail Rev. 2019;24:709-23.

57. Bunyavanich S, Do A, Vicencio A. Nasal gene expression of angiotensin-converting enzyme 2 in children and adults. JAMA. 2020;323:2427-9

58. Wysocki J, Ye M, Rodriguez E, González-Pacheco FR, Barrios C Evora $\mathrm{K}$, et al. Targeting the degradation of angiotensin II with recombinant angiotensin-converting enzyme 2: prevention of angiotensin II-dependent hypertension. Hypertension. 2010;55:90-8

59. Serfozo P, Wysocki J, Gulua G, Schulze A, Ye M, Liu P, et al. Ang II (Angiotensin II) conversion to angiotensin-(1-7) in the circulation is POP (prolyloligopeptidase)-dependent and ACE2 (angiotensin-converting enzyme 2)-independent. Hypertension. 2020;75:173-82.

60. Batu ED, Özen S. Implications of COVID-19 in pediatric rheumatology. Rheumatol Int. 2020;40:1193-213.

61. Lu X, Xiang Y, Du H, Wong GW. SARS-CoV-2 infection in children-understanding the immune responses and controlling the pandemic. Pediatr Allergy Immunol. 2020;31:1-5.

62. Dhochak N, Singhal T, Kabra SK, Lodha R. Pathophysiology of COVID-19: why children fare better than adults? Indian J Pediatr. 2020:2020:1-10.

63. Cascella M, Rajnik M, Cuomo A, Dulebohn SC, Di Napoli R. Features, Evaluation and Treatment Coronavirus (COVID-19). StatPearls. Available from: https://www.ncbi.nlm.nih.gov/books/NBK554776/. [Last accessed on 2020 May 01].

64. Petrilli CM, Jones SA, Yang J, Rajagopalan H, O'Donell LF, Chernyak Y, et al. Factors associated with hospitalization and critical illness among 5279 peoples with coronavirus disease 2019 disease in New York City: prospective cohort study. BMJ. 2020;369:1-15.

65. Ishiyama Y, Gallagher PE, Averill DB, Tallant EA, Brosnihan KB, Ferrario CM. Upregulation of angiotensin-converting enzyme 2 after myo- 
cardial infarction by blockade of angiotensin II receptors. Hypertension 2004;43:970-6

66. Ferrario CM, Jessup J, Gallagher PE, Averill DB, Brosnihan KB, Ann Tallant $\mathrm{E}$, et al. Effects of renin-angiotensin system blockade on renal angiotensin-(1-7) forming enzymes and receptors. Kidney Int. 2005;68:2189-96.

67. Ferrario CM, Jessup J, Chappell MC, Averill DB, Brosnihan KB, Tallant EA, et al. Effect of angiotensin-converting enzyme inhibition and angiotensin II receptor blockers on cardiac angiotensin-converting enzyme 2. Circulation. 2005;111:2605-10.

68. Igase M, Strawn WB, Gallagher PE, Geary RL, Ferrario CM. Angiotensin II AT1 receptors regulate ACE2 and angiotensin-(1-7) expression in the aorta of spontaneously hypertensive rats. Am J Physiol Heart Circ Physiol. 2005;289:H1013-9.

69. Jessup JA, Gallagher PE, Averill DB, Brosnihan KB, Tallant EA, ChappeII MC, et al. Effect of angiotensin II blockade on a new congenic model of hypertension derived from transgenic ren-2 rats. Am J Physiol Heart Circ Physiol. 2006;291:H2166-72.

70. Ocaranza MP, Godoy I, Jalii JE, Varas M, Collantes P, Pinto M, et al. Enalapril attenuates downregulation of angiotensin-converting enzyme 2 in the late phase of ventricular dysfunction in myocardial infarcted rat. Hypertension. 2006;48:572-8.

71. Soler MJ, Ye M, Wysocki J, William J, Lloveras J, Batlle D. Localization of ACE2 in the renal vasculature: amplification by angiotensin II Type 1 receptor blockade using telmisartan. Am J Physiol Renal Physiol. 2009;296:F398-405.

72. Lo CS, Liu F, Shi Y, Maachi H, Chenier I, Godin N, et al. Dual RAS blockade normalizes angiotensin-converting enzyme-2 expression and prevents hypertension and tubular apoptosis in Akita angiotensinogen-transgenic mice. Am J Physiol Renal Physiol. 2012;302:F840-52.

73. Yang Z, Yu X, Cheng L, Miao LY, Li HX, Han LH, et al. Effects of enalapril on the expression of cardiac angiotensin-converting enzyme and angiotensin-converting enzyme 2 in spontaneously hypertensive rats. Arch Cardiovasc Dis. 2013;106:196-201.

74. Klimas J, Olvedy M, Ochodnicka-Mackovicova K, Kruzliak P, Cacanyiova S, Kristek F, et al. Perinatally administered losartan augments renal ACE2 expression but not cardiac or renal mas receptor in spontaneously hypertensive rats. J Cell Mol Med. 2015;19:1965-74.

75. Collister JP, Hendel MD. The role of Ang (1-7) in mediating the chronic hypotensive effects of losartan in normal rats. J Renin Angiotensin Aldosterone Syst. 2003;4:176-9.

76. Caldeira D, Alarcão J, Vaz-Carneiro A, Costa J. Risk of pneumonia associated with use of angiotensin converting enzyme inhibitors and angiotensin receptor blockers: systematic review and meta-analysis. BMJ. 2012;345:1-20

77. Hsu WT, Galm BP, Schrank G, Hsu TC, Lee SH, Park JY, et al. Effect of renin-angiotensin-aldosterone system inhibitors on short-term mortality after sepsis: a population-based cohort study. Hypertension. 2020;75:483-91.

78. Furuhashi M, Moniwa N, Mita T, Fuseya T, Ishimura S, Ohno K, et al. Urinary angiotensin-converting enzyme 2 in hypertensive patients may be increased by olmesartan, an angiotensin II receptor blocker. Am J Hypertens. 2015;28:15-21.
79. Deng Y, Liu W, Liu K, Fang YY, Shang J, Zhou L, et al. Clinical characteristics of fatal and recovered cases of coronavirus disease 2019 (COVID-19) in Wuhan, China: a retrospective study. Chin Med J. 2020;113: 1261-7.

80. Basu R, Poglitsch M, Yogasundaram H, Thomas J, Rowe BH, Oudit GY. Roles of angiotensin peptides and recombinant human ACE2 in heart failure. J Am Coll Cardiol. 2017;69:805-9.

81. Andersen MB, Simonsen U, Wehland M, Pietsch J, Grimm D. LCZ696 (valsartan/sacubitril)--a possible new treatment for hypertension and heart failure. Basic Clin Pharmacol Toxicol. 2016;118:14-22.

82. Meng J, Xiao G, Zhang J, $\mathrm{He} X, \mathrm{O} M \mathrm{M}, \mathrm{Bi} J$, et al. Renin-angiotensin system inhibitors improve the clinical outcomes of COVID-19 patients with hypertension. Emerg Microbes Infect. 2020;9:757-60.

83. Liu WJ, Zhao M, Liu K, Xu K, Wong G, Tan W, et al. T-cell immunity of SARS-CoV: implications for vaccine development gainst MERS-CoV. Antiviral Res. 2017;137:82-92.

84. Huang C, Wang Y, Li X, Ren L, Zhao J, Hu Y, et al. Clinical features of patients infected with 2019 novel coronavirus in Wuhan, China. Lancet. 2020;395:497-506

85. Alba-Leonel A, Carvajal A, Fierro I, Castillo-Nájera F, Campos-Ramos O, Villa-Romero $\mathrm{A}$, et al. Prescription patterns of antihypertensives in a community health centre in Mexico city: a drug utilization study. Fundam Clin Pharmacol. 2016;30:276-81.

86. Silva AC, Diniz JS, Filho AR, Santos RA. The renin angiotensin system in childhood hypertension: selective increase of angiotensin-(1-7) in essential hypertension. J Pediatr. 2004;145:93-8.

87. Silva AC, Diniz JS, Pereira RM, Pinheiro SV, Santos RA. Circulating renin angiotensin system in childhood chronic renal failure: marked increase of angiotensin-(1-7) in end-stage renal disease. Pediatr Res. 2006;60:734-9.

88. Tikoo K, Patel G, Kumar S, Karpe PA, Sanghavi M, Malek V, et al. Tissue specific up regulation of ACE2 in rabbit model of atherosclerosis by atorvastatin: role of epigenetic histone modifications. Biochem Pharmacol. 2015;93:343-51.

89. Qiao W, Wang C, Chen B, Zhang F, Liu Y, Lu Q et al. Ibuprofen attenuates cardiac fibrosis in streptozotocin-induced diabetic rats. Cardiology. 2015;131:97-106.

90. Mortensen EM, Nakashima B, Cornell J, Copeland LA, Pugh MJ, Anzueto $A$, et al. Population-based study of statins, angiotensin II receptor blockers, and angiotensin-converting enzyme inhibitors on pneumonia-related outcomes. Clin Infect Dis. 2012;55:1466-73.

91. Henry C, Zaizafoun M, Stock E, Ghamande S, Arroliga AC, White HD. Impact of angiotensin-converting enzyme inhibitors and statins on viral pneumonia. Proc (Bayl Univ Med Cent). 2018;31:419-23.

92. Day M. Covid-19: ibuprofen should not be used for managing symptoms, say doctors and scientists. BMJ. 2020;368:1.

93. Fang L, Karakiulakis G, Roth M. Are patients with hypertension and diabetes mellitus at increased risk for COVID-19 infection? Lancet Respir Med. 2020;8:e21.

94. Voiriot G, Philippot Q, Elabbadi A, Elbim C, Chalumeau M, Fartoukh M. Risks related to the use of non-steroidal anti-inflammatory drugs in community-acquired pneumonia in adult and pediatric patients. J Clin Med. 2019:8:1-10. 